\title{
The development of coping strategies for young people to construct their identity in times of the COVID-19 pandemic
}

\begin{tabular}{|c|c|}
\hline \multicolumn{2}{|c|}{$\begin{array}{l}\text { Valérie Cohen-Scali }{ }^{1} \text { (1) } \\
\text { Whitney Erby }{ }^{2}\end{array}$} \\
\hline \multicolumn{2}{|c|}{$\begin{array}{l}\text { Affiliations: } \\
{ }^{1} \text { National Institute for Labor } \\
\text { Studies and Vocational } \\
\text { Guidance, Conservatoire } \\
\text { National des Arts et Métiers, } \\
\text { Paris, France }\end{array}$} \\
\hline \multicolumn{2}{|c|}{$\begin{array}{l}\text { ynch School of Education, } \\
\text { Boston College, Chesnut Hill, } \\
\text { United States of America }\end{array}$} \\
\hline \multicolumn{2}{|c|}{$\begin{array}{l}\text { Corresponding author: } \\
\text { Valérie Cohen-Scali, } \\
\text { valerie.cohenscali@lecnam. } \\
\text { net }\end{array}$} \\
\hline $\begin{array}{l}\text { Dates: } \\
\text { Received: } 13 \\
\text { Accepted: } 31 \\
\text { Published: } 20\end{array}$ & $\begin{array}{l}\text { May } 2021 \\
\text { Aug. } 2021 \\
\text { Oct. } 2021\end{array}$ \\
\hline \multicolumn{2}{|c|}{$\begin{array}{l}\text { How to cite this article: } \\
\text { Cohen-Scali, V., \& Erby, W. } \\
\text { (2021). The development } \\
\text { of coping strategies for } \\
\text { young people to construct } \\
\text { their identity in times of } \\
\text { the COVID-19 pandemic. } \\
\text { African Journal of Career } \\
\text { Development, 3(1), a38. } \\
\text { https://doi.org/10.4102/ } \\
\text { ajcd.v3i1.38 }\end{array}$} \\
\hline \multicolumn{2}{|c|}{$\begin{array}{l}\text { Copyright: } \\
\text { (c) 2021. The Authors } \\
\text { Licensee: AOSIS. This } \\
\text { is licensed under the } \\
\text { Creative Commons } \\
\text { Attribution License. }\end{array}$} \\
\hline \multicolumn{2}{|l|}{ Read online: } \\
\hline 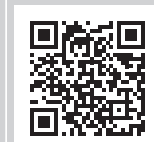 & $\begin{array}{l}\text { Scan this QR } \\
\text { code with your } \\
\text { smart phone or } \\
\text { mobile device } \\
\text { to read online. }\end{array}$ \\
\hline
\end{tabular}

Background: The global coronavirus disease 2019 (COVID-19) pandemic has had a major impact on young people across the world. Many students struggle to complete their studies amidst the pressure of the pandemic and have many difficulties constructing their identity and career which is crucial at this period of life. An overview of the main effects of the pandemic on their identity and career development is presented.

Objectives: The first objective is to highlight the challenges faced by youth regarding their identity and career development, particularly the challenges induced by the COVID-19 pandemic. The next objective is to explore different strategies that may be implemented to ameliorate the effects of the career shock induced by the pandemic. Lastly, the goal is to propose career guidance and counselling interventions that professionals may utilise to help young adults to cope with the career-related consequences of the COVID-19 pandemic.

Method: This article was informed by an overview of the current psychosocial literature. Relevant literature was reviewed and critically analysed. It was also informed by the review of an empirical experience with a group of students who kept diaries during pandemic confinement periods.

Results: The analysis resulted in three sets of psychosocial strategies that youth can develop in order to face the difficulties associated with the COVID-19 pandemic. Each set of coping strategies is related to a specific career intervention that may be implemented by career guidance and counselling practitioners.

Conclusion: To support the development of adaptive coping strategies for the youth, career and counselling professionals need to address the three main types of challenges that are described.

Keywords: COVID-19; identity; coping strategies; career interventions; students.

\section{Introduction}

Young people, particularly students from many countries around the world are suffering from the effects of the coronavirus disease 2019 (COVID-19) pandemic and the confinement that it has produced (Akkermans, Richardson, \& Kraimer, 2020; Blustein \& Guarino, 2020). Not only have young people had to deal with the uncertainty in which they are immersed, but they have also been confronted with disruptions to their personal and professional lives (Blustein et al., 2020; Mariot, Mercklé, \& Perdoncin, 2021). This upheaval in their professional lives has been defined as a career shock, which is described as:

$[A]$ disruptive and extraordinary event that is, at least to some degree caused by factors outside the focal individual's control and that triggers a deliberate thought process concerning one's career. (Akkermans, Seibert, \& Mol, 2018, p. 4; see also Akkermans et al., 2020)

The COVID-19 pandemic presents several aspects of a career shock for the youth, especially for students, many of whom have been forced to re-consider their career choices (Belghith, Ferry, Patros, \& Tenret, 2020). Students have been forced to change their lifestyles, to convert to on-line studying, and to relinquish their internships in companies both domestic and abroad. Career shocks can influence the way people manage their careers and make decisions about their future. Like other transition situations (Anderson, Goodman, \& Schlossberg, 2011), career shocks can have short-, medium- and long-term effects that are difficult to predict, but which are not necessarily negative. On the contrary, they can induce positive effects, constitute opportunities and lead to changes for a more satisfying life. Thus, it is also possible to associate the effects of the 
pandemic with epiphanies, described as 'interactional moments and experiences (that) alter the fundamental meaning structure' and 'leave marks on people's lives' (Denzin, 2014, p. 52). The COVID-19 pandemic may be called a major professional event for some people, given that it is 'touching every fabric of ... life' (Denzin, 2014, p. 53). Nevertheless, this major professional event can destabilise a well-established and long-standing career system in some way. This is the case for many students who have a wellestablished professional project or those who work in the restaurant or cultural sector and who can no longer work because of the suspension of these activities. These situations also underline that a career is a complex psychosocial construct, as underscored by The Chaos Theory of Careers (Bright \& Pryer, 2011). This theory underlines that careers are dynamic and complex open systems that are very sensitive to changes and that predictions about what is going to happen next are very difficult to draw. The Life Design approach highlights the place of identity as a psychological regulator when many changes appear in people's lives. The major psychological activity of 'self constructing' (Collin \& Guichard, 2011; Guichard, 2009) and of 'career construction' (Savickas, 2011) recognises identity as a fundamental resource that supports career development (Pouyaud, 2015).

\section{Goals of the study}

Firstly, the goal of the study is to identify the main psychological and social effects of the pandemic on the career choices and career paths of young people in France and the United States. The guiding explorative research questions are as follows: To what extent might the COVID-19 pandemic make identity construction more difficult and how might young people react? Secondly, a goal is to discuss various global coping strategies that may be implemented by young adults to manage the career shocks induced by the pandemic. Thirdly, we aim to examine the role of career interventions in supporting young adults in their self-construction in this specific context.

\section{Research methodology}

The methodology was based on two processes. Firstly, we conducted a brief, adapted qualitative review of the psychosocial literature related to identity and career development in social crisis situations. Groups of papers that were examined possessed the characteristics that are relevant to the phenomenon studied (Booth, 2001). Subsequently, the findings were integrated and synthesised, using the following procedure:

The abstracts for material from a number of databases were identified. We started by engaging in a systematic reading of the abstracts using the terms 'COVID-19', 'identity', and 'career development'. We simultaneously searched articles and book chapters in both French and English from a wide range of sources. We assessed the data and removed duplicate sources when necessary. Then, after reading the articles, we determined the appropriateness of each source, before incorporation into the corpus. General inclusion criteria were sources addressing (1) identity, (2) career development, (3) students (4) crisis. Exclusion criteria were articles not related to these thematics.

An empirical based method has also been implemented in order to capture the students' perception of their situation. Indeed, this synthesis has been enriched by the implementation of a photobiographic diary conducted with a group of 7 masters' students at a University in Paris, during a 1-month confinement period in France in November 2020. Each student volunteer was asked to keep a daily photo diary. The instructions given to them were as follows: 'Take a photo each day that corresponds to your current mood and write a few lines to describe your feelings at this moment'. The students kept the daily photo diary for 1 month. Afterwards, content analysis of the diary photos and writing was conducted. This work helped to identify the main psychological difficulties that the students experienced and the main coping strategies that were developed in order to address them. This experiment had a status of confirmatory analysis (Booth, 2001).

\section{Rigour of the study}

Each step of the study was rigorously conducted. The main content of this study was first presented at the online Cannexus Congress (Cohen-Scali, 2021) to career counselling practitioners who made comments and provided feedback regarding their own professional experience. Their comments and suggestions have been considered to improve and clarify the present study.

\section{Synthesis of the findings}

In this first section, the main psychological effects of the pandemic on young adults are described. In the following section, we explore the ways in which the pandemic may be associated with an identity threat for youth, and the coping strategies that emerge as a result. The third section outlines the connection between these coping strategies and the career counselling interventions needed to develop them. We conclude briefly with a reflexion on the challenges associated with the construction of innovative career counselling interventions.

\section{Main psychological effects of the pandemic on young adults}

The COVID-19 pandemic can be analysed as a career shock for the youth that might affect their identity construction in diverse ways.

\section{The pandemic as a multifaceted shock to career construction for students}

This section highlights the different facets of career shock induced by the pandemic for young people, particularly in France and the United States. 
Since the COVID-19 pandemic began, many young people in some vocational training courses most affected by the pandemic (tourism, catering, hospitality, culture, etc.) were not able to complete internships or apprenticeships in a company. The absence of these corporate experiences makes it impossible to develop hands-on professional and organisational socialisation, which is central to allowing students to learn about the world of work and refine their professional projects. Indeed, organisational socialisation is the process by which an individual learns the 'ropes' of an organisational role and develops the knowledge and skills necessary to assume this role (Van Mannen \& Schein, 1979). It allows individuals to move from being an 'outsider' of the company, to being a participatory and effective member (Feldman, 1976). This activity involves the search for information, social interactions with professionals, and the development of adaptive strategies (Morrison, 1993). During these internship experiences, newcomers initiate organisational identity work, which refers to how individuals shape a sense of self vis-à-vis their environment (Kreiner \& Murphy, 2016, p. 278; see also Kreiner, Hollensbe, \& Sheep, 2006) which leads to the development of the aptitude to build organisational identities and to move from one identity to another.

More generally, these corporate activities help young people to move into adulthood and influence professional identities in construction. They can be considered as rites of passage promoting autonomy, responsibility, self-confidence and can thus help youth to become adults (Mortimer \& Shanahan, 2003). Corporate immersions include a didactic dimension by enriching academic teaching, offering opportunities to learn differently, through observation and action (Glaymann, 2015). Many young people in education and vocational training have seen their training trajectory become destabilised. Moreover, the pandemic has resulted in the impoverishment of young people in both France and the United States, because of numerous job losses, in particular odd jobs for students. More than 700000 salaried jobs have been lost in France, particularly in sectors in which young adults work such as hotels and restaurants, sports and leisure, and tourism. At the end of 2020, the unemployment rate for young people in France rose to $28 \%$. Additionally, $36 \%$ of students in France have had their paid activity interrupted (Belghiti et al., 2020). In the United States, the unemployment rate for workers between the ages of 16 and 24 was 25.3\% during the peak of the pandemic in April 2020 (BLS, 2020). Many young people who have no social support resort to social assistance, charities, and NGOs for basic necessities such as food and shelter. Furthermore, most young people are unsettled when it comes to plans for the future. This additional income not only played an economic role for young people from disadvantaged backgrounds, allowing them to meet their basic needs, but these jobs also had an important role in the construction of professional identity (Finch, Mortimer, \& Ryu, 1997) fostered adaptability (Monteiro \& Almeida, 2015) and commitment in work (Sortheix, Dietrich, Chow, \& Salmena-Aro, 2013).
Another facet of the career shock is linked to the switch to distance learning. This situation does not allow students to fully experience the status of being a student and does not allow student socialisation and the development of the 'student profession' (Coulon, 1997). In France, the socialisation of students varies according to the universities (Orange, 2017; Paivandi, 2015). Mutual aid between students, the presence of teachers, support systems for students who experience difficulty (tutoring, additional training in the methodology, education support, etc.), as well as social, cultural, and union activities that are irreplaceable for a successful integration into the University, have been almost completely cancelled. In addition to this lack of socialisation, which is particularly felt by undergraduate students, distance education carried out without sufficient preparation does not always offer good learning conditions.

In some regions of France, 25\% of students do not have a working computer and only $17.6 \%$ have access to a stable, fast, and unlimited internet connection (Martin \& Paye, 2020). In the United States, a recent survey revealed that more than 9 million school children do not have consistent access to reliable internet facility at home (DES, 2018). This is particularly true for students from lower-income backgrounds. In these conditions, it is difficult to follow the lessons and to do teamwork. A survey carried out in France at the start of the pandemic in April and May 2020 (Mariot et al., 2021), showed that $36 \%$ of young people aged $18-24$ reported that they never leave their homes (compared to $25 \%$ of the total population). About $46 \%$ of students have moved to new housing accommodations and have returned to live with their parents. Similarly, in the United States, the percentage of young adults aged 18-29 living at home with at least one of their parents has risen to $52 \%$, which is the highest level recorded since the Great Depression (Anderson \& Kumar, 2020). These different elements, as well as the fear for their health and that of their relatives have led many students in both France and the United States to develop psychological distress. Many of these students suffer from social isolation, especially foreign students. Young people aged 18-30 were the category of the population most affected by the loss of social relations (46.4\% against 37.2\% amongst 37-45-year-olds) (Mariot et al., 2021). Moreover, a portion of students claim that they feel exhausted (35\%), feel psychological distress (31\%), despondency or sadness (28\%), and discouragement (16\%) (Belghiti et al., 2020). There is also an increase in alcohol consumption and addictions, especially to drugs and to video games.

During the pandemic, social ties have been more difficult to maintain, whilst support from relatives and the mobilisation of support networks remains particularly crucial. A consequence has also been that one in four young people in France (Belghiti et al., 2020) had to modify their professional or training plan or wish to stop their studies. Of these young people, $8 \%$ of them wish to find new training opportunities or are looking for a new career choice and $4 \%$ plan to interrupt their studies following confinement. Additionally, some students have questioned the relevance of their projects. Specifically, $45 \%$ of 
students are pessimistic about their professional integration possibilities. Students in the United States have had similar experiences. A study of US college students found that $13 \%$ of students who were surveyed reported that they delayed graduation whilst $40 \%$ reported that they had lost a career opportunity including a job or internship. Furthermore, 29\% of students reported that they expect to earn less money when they are 35 years old (Aucejo, French, Araya, \& Zafar, 2020). Clearly, the lifestyles, self-perceptions and plans of young people have been strongly shaken by this pandemic. Thus, most young people from the middle and underprivileged classes of France encounter the same concerns as many young people from the countries of the Global South, for whom the struggle for survival is daily and who often do not have the opportunity to build projects. We are therefore confronted with a generalised development of the economic and social precariousness of youth.

Given that youth is a period of life that often involves decisions around vocational choice and labour market integration, the consequences of this crisis have had particularly substantial effects on the professional identity development of young people.

\section{The identity construction of young people challenged by the global pandemic}

Identity is structured and organised from childhood and takes shape in adolescence. As Erikson explains:

[Identity formation] begins where the usefulness of identification ends. It arises from the selective repudiation and mutual assimilation of childhood identifications and their absorption in a new configuration, which, in turn, is dependent on the process by which a society (often through subsocieties) identifies the young individual recognizing him as somebody who had to become the way he is, and who, being the way he is, is taken for granted. (Erikson, 1959, in McAdams \& Zapata-Gietl, 2015, p. 82)

During adolescence, ego is under the pressure of two opposing poles: identity synthesis and identity confusion (Erikson, 1968). Identity synthesis is a resumption of past and present identifications in a larger set of ideals relating to oneself and determined by oneself. It leads to registering one's present in an anticipated future. Identity synthesis corresponds to the synchronic and diachronic integration of the young person's seemingly disparate aspects of the self, including their varied and possible conflicting roles, relationships, values, and beliefs. It provides a sense of unity of the self. Identity confusion, on the other hand, refers to an inability to develop a coherent set of ideals on which to build one's adult identity. In adolescence, this sense of continuity and coherence develops, and a set of goals, values, and beliefs emerge that constitute the uniqueness of each individual. In emerging adults (Arnett, 2000) and young adults, this process of defining oneself 'in a certain way' crystallises under the influence of contexts, experiences, and social relationships. The period of young adulthood is a phase in which relationships of intimacy, partnership and affiliation with others are built up, which allows the emergence of a feeling of belonging to an age group united in a community and sharing a collective culture. Subsequently, Marcia (Marcia, Waterman, Matteson, Archer, \& Orlofsky, 1993) brought to light the importance of the processes of exploration of oneself and of one's environment, as well as the role of engagement in activities on identity building. These two dimensions make up four identity statuses: foreclosure, achieved identity, identity diffusion and the moratorium.

Young people who do not explore their environment and quickly engage in a lifestyle choice or activity have been associated with foreclosure status. Moratorium status corresponds to young people who continue to explore their environment for an extended period. Identity diffusion occurs when young people neither explore nor engage in a career choice. Finally, achieved identity corresponds to a double activity of exploring various professional, ideological, and interpersonal options and possibly making certain commitments (Kroger, 2015; McAdams \& Zapata-Gietl, 2015). For Meeus (2011), this identity development process has three dimensions: commitment, in-depth exploration and reconsideration of commitment. The interplay amongst these dimensions captures the continuous identity dynamic. However, the context of a health crisis inducing a restriction of activity opportunities makes it impossible to implement these psychological processes, which are crucial for the identity development of adolescents and young adults.

\section{The role of strategies to manage career shock induced by the pandemic}

These identity development processes may be difficult to implement because the pandemic may generate threats to identity.

\section{The pandemic as a threat to identity}

In many countries, the pandemic situation has led to periods of confinement, that is to say the obligation to remain at home and limit as much as possible movements and interpersonal face-to-face contact. These periods of confinement can be likened to a situation of rupture in the trajectory of many people and in particular young people. If we refer to de Gaulejac's model of social exclusion (De Gaulejac \& TaboadaLeonetti, 1994), several factors lead to social exclusion. The first factor is economic. The pandemic crisis has increased employment problems and has created employment uncertainties. Individuals whose professional and social positions were fragile before this crisis (informal work, short multi-contract, contract, etc.) may find themselves unemployed, and uncertain if they will be able to resume their jobs after the pandemic. The second factor relates to social ties. The crisis has strained social and family relationships, depriving individuals of social integration into invaluable relational networks. Furthermore, some individuals, especially students, can no longer rely on state protection and welfare policies for support. Finally, the last factor is symbolic. 
Individuals are often evaluated based on their social utility. People who do not meet these standards are perceived to be of little value to society. These societal demands can lead to feelings of failure and a sense of self-devaluation.

These factors form the backdrop for the biographical breaks as a first step in the process of social exclusion. This step is characterised by a loss arousing a strong negative emotion (it can be initiated by the death of a loved one, a loss of employment, a long illness, a sudden disability, a traumatic accident ...) that:

[T] he individual fails to master or manage emotionally or materially. Sometimes she denies the rupture, not accepting reality, sometimes she maintains unrealistic solutions cultivating the fiction of an immediate outcome. At this stage, the rupture is above all psychological. Most of the time, the individual stays in his home environment while changing his attitude. It becomes versatile: anger, calm, and despondency follow one another alternately, eroding the image of oneself. (De Gaulejac \& Taboada-Leonetti, 1994, p. 118)

The types of reactions reported (Belghiti et al., 2020; Mariot et al., 2021), show that many young people during the pandemic are experiencing such objective and subjective ruptures. In addition, this very first rupture induces a higher sensitivity to further ruptures. Indeed, the way in which the initial rupture is managed can lead the individual to be more vulnerable to other difficulties and additional ruptures.

Each break in life might challenge and weaken the usual functioning of identity. For Breakwell $(1986,2001)$ breaks and abrupt transitions, such as the loss of a job, or feeling constitute threats to identity. To this view, identity has two planes: A Content Dimension with all the characteristics which define social (group memberships, roles, social categories labels, etc. ) and personal identity (values, attitudes, cognitive style, etc.). The other plane is the Value Dimension. Each element of the identity content dimension has a positive or negative value and corresponds to the affective and emotional aspects of identity (Breakwell, 2001). These elements compose the structure of identity and are regulated by two processes. On the one hand, assimilation-accommodation refers to the way in which individuals integrate and interpret new information and incorporate it into their identity. It also includes the subsequent adjustment that takes place so that this information becomes part of the identity structure. On the other hand, the evaluation corresponds to the processes of meaning making and giving value to the elements contained in identity (seeing certain aspects of oneself as positive or negative). Moreover, these processes of identity are guided in their operation by four principles that are desirable states for the structure of identity, at least in Western societies. These principles vary across the life span and the social contexts: continuity in time and space, uniqueness (or the fact of being distinguished from others) feeling confident and in control of one's life, and sense of personal worth (Jaspal \& Breakwell, 2014). Threats to identity are situations that challenge continuity, distinctiveness, or self-esteem and are the product of social influence processes set into motion by the changing pattern of intergroup and interpersonal relationships in the pandemic context:

[A] threat to identity occurs when the processes of identity, assimilation-accommodation and evaluation are, for some reason, unable to comply with the principles of continuity, distinctiveness and self-esteem, which habitually guide their operation. The reason for this obstruction constitutes the threat. (Breakwell, 1986, pp. 46-47)

Job losses, social isolation, the inability to engage in normal social relations, and massive uncertainty about the future can challenge feelings of continuity and coherence, but also the feeling of self-worth. These experiences therefore disrupt the processes of regulating identity. Situations of major disruption constitute threats affecting identity processes and principles which then require individuals to develop coping strategies.

\section{Coping with threat to identities}

For Kastersztein (1990), people living with threats to identity produce specific strategies. These strategies are implemented to overcome difficulties in achieving certain goals, or 'identity victories'. These strategies are:

[I]ndividual or collective behaviours, conscious or unconscious, adapted or unsuitable, put in place to achieve these victories against an adversary who can be oneself, others in concrete interaction, or the social system. (Kastersztein, 1990, p. 31)

Individuals produce strategies related to their perception of what is involved in the situation, the issues, and the perceived goals. Individuals who feel a sense of identity threat can pursue three objectives. The first objective is Differentiation. Differentiation results in psychological processes that lead the person to move towards new behaviours and living spaces, and to invent new dimensions of judgements or evaluations of ways of being with others. The second objective is social visibility. To reach this objective, individuals aim to become visible, or to obtain full recognition of their existence in the eyes of others. They want to have their value recognised to 'count for something'. The third objective is Individuation or Singularisation. This objective leads to affirming one's singularity, or one's difference through creativity and the production of works. Singularisation is a psychological necessity that must be expressed for all individuals, whatever the context.

Coping strategies to face identity threat are defined as 'Any thought or action which succeeds in eliminating or ameliorating threat can be considered a coping strategy, whether it is consciously recognized as intentional or not' (Breakwell, 1986, p. 79). These strategies can have different targets. They can be targeted towards withdrawal from the social context, particularly the material, social or ideological aspects which generate threat. The individual may move into a new, less threatening social position. Another option is to revise the identity structure, based on the content or value dimensions to allow identity to work in accordance with the different identity principles of continuity, distinctiveness, and self-esteem. 
Three families of coping strategies have been pinpointed. Firstly, intrapsychic strategies aim to modify the relationship with oneself, with processes relating to the representations that the person has of themselves and of the problem encountered. These are related to the assimilation-accommodation processes. They are based on two categories: deflection strategies and acceptance strategies. Deflection strategies entail the refusal to modify either the value or content dimensions of identity (deny, depersonalisation, fantasy, etc.). The acceptance strategies result in the revision of one or both dimensions of identity in a manner congruent with threat. They can result in changes inducing a loss of positivity and distinctiveness or the development of a new outlook on oneself which reinforces a sense of self-worth. Indeed, these acceptance strategies 'represent creative adaptations which may rely upon preliminary redefinition and re-attribution tactics' (Breakwell, 1986, p. 93).

Secondly, Interpersonal strategies refer to a modification of relationships with others to cope with threat, or a modification of social interactions, and can result in movement towards a less threatening position. These strategies relate to actions involving negotiation with others. The interactionist approaches of identity have broadly documented this set of actions underlining the way roles can be modified regarding the contexts (Goffman, 1963).

Thirdly, intergroup strategies refer to the relationship with society and with other social groups. These strategies consist of individuals utilising their various affiliations to limit perceived threats. The attitudes of others towards the person can be modified according to their knowledge of the person's belonging to certain other groups. Additionally, group support and group action are strong coping strategies involving intergroup dynamics. Intergroup strategies include joining with people who share similar difficulties, in order to help each other by seeking and sharing information and by building a collective awareness of the problem encountered so that group members can become stronger.

A combination of these strategies can be used to enable young people to face the numerous and significant difficulties caused by the pandemic crisis.

\section{Career Interventions to develop coping strategies}

In this final section, we examine the career counselling activities that could be implemented to support the development of these three groups of coping strategies (Breakwell, 1986). Then, we present a set of three existing innovative career counselling interventions that involve both individual and collective action, and can be used to encourage students to develop the types of coping strategies that may be more useful to them.

\section{Coping strategies through career counselling activities to support meaning making}

We have identified nine groups of activities based on the coping strategies presented that are related to the cognitive, emotional, and behavioural activities that can be used to support students in the development of strategies to face identity threats during the pandemic (Table 1).

These activities are aimed at meaning-making for the individual and the development of self-perception, ideas of how the self is perceived by others, and the perception of others. It is a set of transformative activities by individuals based on their own perceptions. As Malrieu (2003) explains:

The individual gives meaning to each of their activities and becomes a person by extracting it from its domain of origin, by referring it to one or more other domains, within which it is in turn designated and resigned. Indeed, to distance from a situation that generates dissatisfaction, its objectification must occur in an orderly chain of memories. The past must be the object of an intellectual activity oriented towards the search for the conditions of each event. (p. 67)

These activities which are focused on communication make it possible to reconsider the meanings of the different facets of the self and of identity offered in a society and to renegotiate and redefine one's roles. These activities promote the establishment of a new intersubjective convention (Barbier, 2006). They focus on self-development. Processes of selfregulation, intentional self-development and identity construction are intimately linked to the linguistic structures (Brandtstädter, 1999). According to Bakhtin (1977) 'it is not mental activity that organizes expression, but it is expression that organizes mental activity, which models it and determines its orientation' ( $p$ 122-123). Most of the activities presented in Table 1 need language and dialogues to be implemented and contribute to acting towards creating meaning (meanacting).

Meanacting has a directionality and involves creating signs towards what the person might become. It also contributes to meaning through the creation of new signs. As explained by

TABLE 1: Cognitive, Emotional, and behavioural activities supporting the development of three sets of coping strategies amongst students, to face identity threat during the pandemic crises.

\begin{tabular}{|c|c|c|c|}
\hline Coping strategies & Intrapsychic & Interpersonal & $\begin{array}{l}\text { Intergroup / } \\
\text { collective }\end{array}$ \\
\hline $\begin{array}{l}\text { In connection with } \\
\text { Cognitive activity }\end{array}$ & $\begin{array}{l}\text { Development of } \\
\text { Reflectivity } \\
\text { Learning / Curiosity } \\
\text { Identification of } \\
\text { resources }\end{array}$ & $\begin{array}{l}\text { Building common } \\
\text { goals } \\
\text { Exchange of useful } \\
\text { information } \\
\text { Co-analysis of the } \\
\text { situation } \\
\text { Co-construction of } \\
\text { projects } \\
\text { Consultation }\end{array}$ & $\begin{array}{l}\text { Building common } \\
\text { goals } \\
\text { Identification of } \\
\text { common values } \\
\text { Construction of } \\
\text { criteria defining the } \\
\text { group }\end{array}$ \\
\hline $\begin{array}{l}\text { In connection with } \\
\text { emotional activity }\end{array}$ & $\begin{array}{l}\text { Self-value, } \\
\text { self-confidence } \\
\text { Development of a } \\
\text { Sense of } \\
\text { Effectiveness } \\
\text { Optimism / Hope }\end{array}$ & $\begin{array}{l}\text { Confidence } \\
\text { Care } \\
\text { Empathy } \\
\text { Support } \\
\text { Trust } \\
\text { Feeling of } \\
\text { acceptance } \\
\text { acknowledgement }\end{array}$ & $\begin{array}{l}\text { Sense of belonging } \\
\text { to a chosen group } \\
\text { Sense of usefulness } \\
\text { Collective capacity } \\
\text { development }\end{array}$ \\
\hline $\begin{array}{l}\text { In connection with } \\
\text { behavioural activity }\end{array}$ & $\begin{array}{l}\text { Proactivity } \\
\text { Engagement in } \\
\text { expressive activities } \\
\text { Exploration of } \\
\text { activities }\end{array}$ & $\begin{array}{l}\text { Mutual aid } \\
\text { Carrying out joint } \\
\text { actions Co- } \\
\text { monitoring } \\
\text { Consultation } \\
\text { Cooperation }\end{array}$ & $\begin{array}{l}\text { Conducting } \\
\text { collective actions } \\
\text { Aimed at improving } \\
\text { the situation } \\
\text { Development of new } \\
\text { possibilities of being } \\
\text { and doing } \\
\text { Production of } \\
\text { innovations }\end{array}$ \\
\hline
\end{tabular}


Josephs, Valsiner and Surgan et al. (1999) 'the sign prepares the person for new encounters with the world that might happen, but that are not to be taken for granted' (p. 258). The sign may be an internal representation of a desired event or action that guided intention to act. The process of meaningmaking involves the development of intentionality, defined as 'the capacity to perform an action on purpose' (Mascolo, Fischer, \& Neimeyer, 1999, p. 147).

The role of career counselling is to engage individuals in a quest for a different perspective on their lives. It involves a process of deconstruction-reconstruction and co-construction (Savickas, 2011). The goal is to revise the individuals' understanding of their life. In the following section, we introduce three career counselling intervention models based on existing narrative techniques that could encourage the development of coping strategies described above to support students who are facing difficulties connected to the consequences of the COVID-19 pandemic.

\section{Models of career counselling and guidance interventions supporting the development of these coping strategies}

The three models briefly introduced below must be incorporated into guidance intervention systems to help young people, especially students, to face the current crisis, and to strengthen their identities by acting at the intrapsychic, interpersonal, and collective levels. The three models are the Life Design counselling approach (Savickas, 2012), Contextual Action Theory and practice (Young, Domene, \& Valach, 2015) and the emancipatory livelihood guidance approach (eds. Hooley, Sultana, \& Thomsen, 2018).

\section{Life design approach and the development of identity skills at the intrapersonal level}

At the intrapersonal level, Life Design can be considered as an approach that is able to support the reorganisation of individual identities and the development of intrapsychic strategies. It allows individuals to become authors of their life and not just actors. As authors of their life, they can increase their capabilities and are not limited to merely reacting to changes. Life Design's interventions contribute to identity changes by activating, stimulating and developing personal resources. This approach aims to give people back some control over their lives. Based mostly on narratives and dialogues, two main methods have been developed in this perspective. These two methods, even if they have different theoretical foundations, can be used separately or one after the other with the aim of activating the reflexivity related to identity organisation. Firstly, Savickas' career construction interview (Savickas, 2011, 2012) is an intervention based on one to three sequences with a counsellor who aims for the co-construction of a new self-portrait of the client. To achieve this self-portrait, the counsellor asks five questions: (1) Who did you admire when you were growing up? (2) Do you read any magazines or watch television shows regularly? (3) What is your favourite book, movie or shows? (4) Tell me your favourite saying or motto (5) What are your earliest recollections? Following this interview, the counsellor prepares a portrait which is discussed with the person. Finally, a set of actions to make the portrait evolve, are defined. This method may help young people to create a clear picture of themselves and of who they want to become.

The second main method is the Life Design Counselling Dialogues (LDCD) of Guichard (Guichard, 2009; Guichard, Bangali, Cohen-Scali, Pouyaud, \& Robinet, 2017). This model is based on the representation of an identity organised in several subjective identity forms (SIF), which can be related to different spheres of life and activities carried out in these life contexts. The intervention makes it possible to visualise and modify the organisation of these different SIFs, thanks to the realisation of a series of interviews (between 2 and 4) and a mapping of the identity system. The intervention also follows four main stages. The first one aims to identify the SIFs of the person in his current and past life. The counsellor helps the person to deepen these SIFs and to explore different aspects of the relationship of the self, with specific objects and with others, in each of their spheres of life. Individuals identify certain relationships with certain activities in these spheres that suit them and others that they would like to develop. Then, they establish links between SIFs and gradually end up considering a more or less important reorganisation of their identity system. Young adults may benefit from this dialogue to enlighten them on the barriers and available supports that may help them to adapt to a new situation.

Overall, research and practices relating to these Life Design interventions have shown that they promote changes in the person's perception of themselves and their future prospects (Pouyaud, Bagali, Cohen-Scali, Robinet, \& Guichard, 2016). Intrapersonal strategies may be developed with these interventions that allows the person to consider one's life differently, and to become more positive, optimistic, and proactive.

The approach described below is based on the development of collaborations with other non-career guidance professionals, who are considered to be the main resources to assist young people with the development of the interpersonal strategies needed to adapt to difficult situations.

\section{The contextual action approach to develop interpersonal strategies}

To promote interpersonal coping strategies, each individual will have to rely on powerful relational resources to define ambitious goals and to form new projects. The contextual action approach (Young et al., 2015) is based on the idea of a conceptual link between action and career. Action corresponds to a behaviour directed towards a goal. Several actions with common objectives are considered as projects. Several similar projects important in the person's life lead to a career. These sets of actions are often designed jointly, with peers, a romantic partner, relatives, a teacher or a counsellor. They emerge from a process of communication and consultation 
which can lead to projects. This approach highlights the role of social interactions and in particular conversations with friends and family to define vocational projects.

Recently, the author has developed career counselling interventions with young newcomers to Canada (Domene, Young, \& Wilson, 2019). It consists of integrating a significant person in their social environment in the reflection and communication on the intentions of action and the projects of the young person, to promote a co-construction of joint actions and projects. Part of the intervention consists of a selfconfrontation, where the person can listen to their story or the conversation in order to deepen their reflection. This intervention makes it possible to develop projects by relying on proximal relationships and by promoting the quality of these interactions:

$[W]$ orking with the significant other person, engaging in joint conversations that are observed and contribute to the identification of the dyad's joint project, and the identification of ways in which the project can be enhanced. (Domene et al., 2019, p. 570)

\section{The emancipatory guidance approach and intergroups coping strategies}

This third approach focuses on the development of intergroup coping strategies. Designed by Hooley et al. (2018), the approach considers Guidance in its political mission, as well as emancipation, and development of the power to act amongst the most deprived or vulnerable people. It focuses less on individual psychological resources, and more on communities in their role of social and political actors. Guidance is conceived as a set of collective and community actions in the fight against oppression, exploitation, inequalities, and precariousness. Guidance interventions must enable people to better understand their social situation by helping them to build a critical awareness and to fight to improve their situation. From this point of view, counsellors are informants on rights but also lawyers who will defend these individuals and help them to make their voice heard. However, it is also about encouraging people to work together, and to support each other to become more influential players in their environment.

This approach promotes collective activities that are likely to have social visibility and assist in the development of individual and collective skills, such as Photovoice, that promotes the creativity of vulnerable groups. It adopts a holistic perspective on careers and encourages young people to think about what makes work decent and life better. Young people come to think about the necessity to live in a fair and equitable society. Interventions are based on career education, experimental learning, group projects, and volunteering. They consider social justice and green guidance and individuals are able to explore the relationship between their lives and the whole context.

These three sets of interventions are necessary in the current context because they offer complementary perspectives to support young people in the development of useful coping strategies allowing them to face identity threats, by offering a wide range of methods that all focus on empowering people individually and collectively.

\section{Limitations of the study}

As this article is based on a selective review and empirical experiences, it is acknowledged that certain sources may not have been available for inclusion. However, the issues raised by this work are strongly documented, especially in relation to identity construction of young adults, in situations of social and individual crisis.

\section{Implications for research, practice, policy, and future research}

This research is relevant to the field of career development, education, and social inclusion and it should prompt further research into the area. In most countries, the COVID-19 pandemic has highlighted the major social and personal difficulties met by young people. This context does not allow identity to follow a positive course of development which leads to career perspectives being questioned. Governments of all countries need to recognise the current problems and rapidly propose policies and practices to support the training, and the social and psychosocial support of this population. Future research will need to implement these sets of career development programmes and evaluate their efficiency on the development of coping strategies for constructing young adults' identity.

\section{Conclusion}

The difficulties imposed by the COVID-19 pandemic, and the need for young adults to develop coping strategies leads to the necessity of new multifaceted career counselling interventions to be conceived in a coordinated manner. Career development interventions must be more than even centred on the reinforcement of competences for the support of identity construction in interaction with others and the larger environment. Practitioners have to face several challenges to develop these innovative interventions (ed. Maree, 2019). Firstly, most counselling and guidance professionals are discovering 'cyber-guidance' during this pandemic. Until the pandemic, it was not customary to offer remote online career counselling interviews. Today, this is becoming the rule. However, access to digital tools and their mastery is the first challenge that must be overcome by clients and practitioners. This is a huge source of inequality given that many families either do not have the devices necessary to connect to the internet, or are sharing a single device amongst an entire family (Anderson \& Kumar, 2020; Brunner \& Maurin, 2019). The second challenge is to conceive more adjusted career interventions. Given the complexity of individual and collective situations, interventions must adopt an engineering perspective. Engineering is defined as 'an activity whose product is conception and evaluation and more broadly the monitoring of an intervention built especially in relationship with a particular situation' (Barbier, 
2017, p.124). This activity relates to the idea of a 'Council' composed of different people (some being practitioners, others being significant persons working together). The aim is to design specific and individualised interventions related to the person's specific questions. Finally, the third challenge is that career counselling interventions need to integrate a global perspective. They must be conceived as a holistic societal mission. This pandemic crisis reinforces the need for guidance to engage in a new paradigm integrating a critical perspective related to both social justice and to the question of climate change and the protection of natural resources.

\section{Acknowledgements Competing interests}

The authors declare that they have no financial or personal relationships that may have inappropriately influenced them in writing this article.

\section{Authors' contributions}

V.C-S. made the conceptualisation of the article. W.E. added specific examples from her country, made the formal analysis, and reviewed the writing.

\section{Ethical considerations}

This article followed all ethical standards for research without direct contact with human or animal subjects.

\section{Funding informations}

This research received no specific grant from any funding agency in the public, commercial or not-for-profit sectors.

\section{Data availability}

The references provide access to the data and information provided in the text.

\section{Disclaimer}

The views and opinions expressed in the article are those of the authors and do not necessarily reflect the official policy or position of any affiliated agency of the authors.

\section{References}

Akkermans, J., Richardson, J., \& Kraimer, M.L. (2020). The Covid-19 crisis as a caree shock: Implications for careers and vocational behavior. Journal of Vocational Behavior, 119, 103434. https://doi.org/10.1016/j.jvb.2020.103434

Akkermans, J., Seibert, S.E., \& Mol, S.T. (2018). Tales of the unexpected: Integrating career shocks in the contemporary careers literature. Journal of Industrial Psychology, 44, a1503. https://doi.org/10.4102/sajip.v44i0.1503

Anderson, M., \& Kumar, M. (2020, May 30). Digital divide persists even as lowerincome Americans make gains in tech adoption. Pew Research Center.
Retrieved from https://www.pewresearch.org/fact-tank/2019/05/07/digitaldivide-persists-even-as-lower-income-americans-make-gains-in-tech-adoption/

Anderson, M.L., Goodman, J., \& Schlossberg, N.K. (2011). Counseling adults in transition. Springer Publishing Company.

Arnett, J.J. (2000). Emerging adulthood: A theory of development from the late teens through the twenties. American Psychologist, 55(5), 469-480. https://doi. org/10.1037/0003-066X.55.5.469

Aucejo, E.M., French, J., Araya, M.P.U., \& Zafar, B. (2020). The impact of COVID-19 on student experiences and expectations: Evidence from a survey. Journal of Public Economics, 191, 104271.
Bakhtin, M. (1977). Le marxisme et philosophie du language [marxism and philosophy of language]. Editions de Minuit.

Barbier, J.M. (2006). Rapports entre sujets et activités [Relationships, between subjects and activities]. In J.M. Barbier \& M. Durand (Eds.), Sujets, activités et environnements [Subjects, activities, and environments]. (pp. 175-220). Presses Universitaires de France.

Barbier, J.M. (2017). Vocabulaire d'analyse des activités [vocabulary of activities analysis] ( $\left.2^{\text {nde }} e d.\right)$. Presses Universitaires de France.

Belghith, F., Ferry, O., Patros, T., \& Tenret, É. (2020). Student life during the Covid-19 pandemic: Uncertainty, transformation, fragility (OVE Infos No. 42). Retrieved

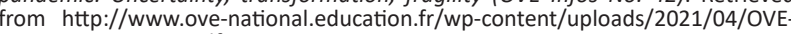
INFOS-42-ENGLISH.pdf

Blustein, D., Duffy, R., Fereira, J., Cohen-Scali, V., Cinamon, R.G., \& Allan, B., (2020). Unemployment in time of COVID-19: A research agenda. Journal of Vocational Behavior, 119, 103436. https://doi.org/10.1016/j.jvb.2020.103436

Blustein, D.L., \& Guarino, P.A. (2020) Work and unemployment in the time of COVID-19: The existential experience of loss and fear. Journal of Humanistic Psychology, 60(5), 702-709. https://doi.org/10.1177/0022167820934229

Booth, A. (2001). Cochrane or cock-eyed? How should we conduct systematic reviews of qualitative research? Paper presented at the qualitative evidence-based practice conference, taking a critical stance. Coventry University, May 14-16, practice conference, taking a critical stance. Coventry University, May 14- Retrieved from https://www.researchgate.net/publication/277255779
2001.

Brandtstädter, J. (1999). The self in action and development. In J. Brandtstädter \& R.M. Lerner (Eds.), Action and development. Theory and research through the life-span (pp. 37-66). Thousand Oaks, CA: Sage.

Breakwell, G.M. (1986). Coping with threatened identities. Methuen, MA: Methuen \& Co.

Breakwell, G.M. (2001). Social representational constraints upon identity. In K. Deaux \& G. Philogena (Eds.), Representations of the social (pp. 271-284). Blackwell Publishers.

Bright, E.M., \& Pryor, R.G. (2011). The chaos theory of careers. Journal of Employment Counseling, 48, 163-166. https://doi.org/10.1002/j.2161-1920.2011.tb01104.x

Brunner, A., \& Maurin, L. (2019). Rapport sur les inégalités en France [report on inequalitiesin France]. Paris: Observatoire des inégalités.

Bureau of Labor Statistics (BLS). (2020, June). Unemployment rises in 2020, as the country battles the COVID-19 pandemic. https://www.bls.gov/opub/mlr/2021/ article/unemployment-rises-in-2020-as-the-country-battles-the-covid-19pandemic.htm

Cohen-Scali, V. (2021). Youth identity in the COVID-19 pandemic and challenges for the career practitioners. Presentation made at the on-line Cannexus Congress, Quebec, Canada, February 1.

Collin, A., \& Guichard, J. (2011). Constructing self in career theory and counselling intervention. In P.J. Hartung and L.M. Subich (Eds.), Constructing self in work and career; Concepts, cases and contexts (pp. 89-106). American Psychological Association.

Coulon, A. (1997). Le métier d'étudiant [student career]. Presses Universitaires de France.

De Gaulejac, V., \& Taboada-Leonetti, I. (1994). La lutte des places [The struggle for places]. Paris: Desclée de Brouwer.

Denzin, N.K. (2014). Interpretative autoethography. Sage.

Digest of Education Statistics (DES). (2018). National Center for Education Statistics (NCES) home page, a part of the U.S. Department of Education. Retrieved from https://nces.ed.gov/programs/digest/d18/tables/dt18_702.40.asp

Domene, J.F., Young, R.A., \& Wilson, C. (2019). Career counselling for emerging adults based on goal-directed action: An innovative approach to theory, research, and practice. In K. Mareer (Ed.), Handbook of innovative career counselling (pp. 557-575). Springer.

Erikson, E. (1959). Identity and the life cycle: Selected papers. Psychological Issues, 1(1), 5-165.

Erikson, E. (1968). Identity: Youth and crisis. Norton.

Feldman, D.C. (1976). A contingency theory of socialization. Administrative Science Quarterly, 21(3), 433-452.

Finch, M., Mortimer, J., \& Ryu, S., (1997). Transition into part-time work: Health, risks and opportunities. In J. Schulenberg, J. Maggs, K. Hurrelman (Eds.). Health, risks and developmental transitions during adolescence (pp. 321-345). Cambridge University Press.

Glaymann, D. (2015). Quels effets de l'inflationdes stages dans l'enseignement supérieur? [What are the effects of the growing numbers of internships in higher education?]. Formation Employ, 129, 5-22. https://doi.org/10.4000/ formationemploi.4340

Goffman, E. (1963). Stigma. Penguin.

Guichard, J. (2009). Self-constructing. Journal of Vocational Behavior, 75(3), 252-258. https://doi.org/10.1016/j.jvb.2009.03.004

Guichard, J., Bangali, M., Cohen-Scali, V., Pouyaud, J., \& Robinet, M.L. (2017). Concevoir et orienter sa vie: les dialogues de conseil en life design [Design and orient one's life: The life design counseling dialogues]. Paris: Qui plus est.

Hooley, T., Sultana, R., \& Thomsen, R. (Eds.). (2018). Career guidance for social justice. Routledge.

Jaspal, R., \& Breakwell, G.M. (2014). Identity process theory. Identity, social action and social change. Cambridge University Press.

Josephs, I.E., Valsiner, J., \& Surgan, S.E. (1999). The process of meaning construction: Dissecting the flow of semiotic activity. In J. Brandtstädter \& R.M. Lerner (Eds.) Action and development. Theory and research through the life-span (pp. 224-257) Thousand Oaks, CA: Sage. 
Kastersztein, J. (1990). Les strategies identitaires des acteurs sociaux: approche dynamique des finalités. [Identity strategies of social players: Dynamic approach of the purposes]. In C. Camilleri, J. Kastersztein, E.M. Lipiansky, H. Malewskastrategies]. (pp. 27-42). Presses Universitaires de France.

Kreiner, G.E., \& Mutphy, C. (2016). Organizational identity work. In M.G. Pratt, M. Schultz, B.E. Ashforth, \& D. Ravasi (Eds.), The Oxford handbook of organizational identity (pp. 276-296). Oxford University Press.

Kreiner, G.E., Hollensbe, E.C., \& Sheep, M.L. (2006). On the edge of identity: Boundary dynamics at the interface of individual and organizational identities. Human Relations, 59(10), 1315-1341.

Kroger, J. (2015). Identity development from adulthood: The move towards the 'wholeness'. In K.C. McLean \& M. Syed (Eds.), The Oxford handbook of identity development (pp. 65-80). Oxford University Press.

Malrieu, P. (2003). La construction du sens dans les dires autobiographiques [Meaning making in autobiography narratives]. Eres.

Marcia, J.E., Waterman, A.S., Matteson, D.R., Archer, S.L., \& Orlofsky, J.L. (1993). Egoidentity: A handbook for psychosocial research. Springer-Verlag.

Mariot, N., Mercklé, P., \& Perdoncin, A., (2021). Personne ne bouge. Une enquête sur le confinement du printemps 2020 [Nobody moves. A survey about the quarantine of spring 2020]. Grenoble: UGA Editions.

Martin, E., \& Paye, S. (2020). Le travail étudiant en période de confinement [The student work during the quarantine period]. Nancy: Université de Lorraine. 19 pages.

Maree, K.G. (Ed.). (2019). Handbook of innovative career counseling. Springer.

Mascolo, M.F., Fischer, K.W., \& Neimeyer, R.A. (1999). The dynamic co-development of intentionality, self and social relations. In J. Brandtstädter \& R.M. Lerner (Eds. Action and development. Theory and research through the life-span (pp. 105-132). Thousand Oaks, CA: Sage.

McAdams, P.D., \& Zapata-Gietl, C. (2015). Three strands of identity developmen across the human life course: Reading Erikson in full. In K.C. McLean \& M. Syed (Eds.), The Oxford handbook of identity development (pp. 81-94). Oxford University Press.
Meeus, W. (2011). The study of adolescent identity formation 2000-2010: A review of longitudinal research. Journal of Research on Adolescence, 21(1), 75-94. https:// doi.org/10.1111/j.1532-7795.2010.00716.x

Monteiro, S. \& Almeida, L. (2015). The relations of career adaptability to work experience, extracurricular activities and work transition in Portuguese Graduates Students. Journal of Vocational Behavior, 91, 106-112. https://doi.org/10.1016/j. jvb.2015.09.006

Morrison, E.W. (1993). Longitudinal study of the effects of information seeking on newcomer socialization. Journal of Applied Psychology, 78(2), 173-183.

Mortimer, J.T., \& Shanahan, M.J. (2003). Handbook of the life course. Springer.

Orange, S. (2017). Democratization of post-secondary education in France: Diverse and complementary institutions. In P.G. Altbach, L. Reisberg, \& H. De Wit (Eds.) Responding to massification (pp. 103-114). Sense Publishers.

Paivandi, S. (2015). Apprendre à l'Université [Learning at university]. De Boeck.

Pouyaud, J. (2015). Vocational trajectories and people's multiple identities: A life design. In L. Nota \& J. Rossier (Eds.), Handbook of life design (59-74). Hogrefe.

Pouyaud, J., Bagali, M., Cohen-Scali, V., Robinet, M.L., \& Guichard, J. (2016). Exploring changes during life and career design dialogues. Journal of Vocational Behavior 97, 3-12. https://doi.org/10.1016/j.jvb.2016.07.008

Savickas, M.L. (2011). Career counseling. American Psychological Association.

Savickas, M.L. (2012). Life design: A paradigm for career Intervention in the 21st century. Journal of Counseling and Development, 90(1), 13-19. https://doi. org/10.1111/j.1556-6676.2012.00002.x

Sortheix, F.M., Dietrich, J., Chow, A., \& Salmena-Aro, K. (2013). The role of career values for work engagement during the transition to working life. Journal of Vocational Behavior, 83(3), 460-475.

Van Mannen, J., \& Schein, E.H. (1979). Toward a theory of organizational socialization. Research in Organizational Behaviour, 1, 209-264.

Young, R.A., Domene, J.F., \& Valach, L. (2015). Counseling and action. Springer. 